\title{
Periglacial Features From Morfee Mountain, North-Central British Columbia
}

\author{
RICHARD D. REVEL ${ }^{1}$
}

\begin{abstract}
Six periglacial features (sorted polygons, sorted steps, sorted nets, sorted stripes, sorted circles, felsenmeer and a possible altiplanation terrace) are described from a new location in Central British Columbia (locally known as Morfee Mountain, $55^{\circ} 26^{\prime} \mathrm{N}, 123^{\circ} 02^{\prime} \mathrm{W}$ ) between $1300-1650 \mathrm{~m}$ elevation. These features are local in distribution over an area of several $\mathrm{km}^{2}$. Observations on specific features indicate a continuum of intermediate forms between sorted nets, sorted polygons and sorted stripes. The elevation of these features supports the suggestion of Brown and Péwe (1973) that the lower elevation of permafrost and periglacial features should rise progressively southward along a north-south transect through the Western Cordillera.
\end{abstract}

RÉSUMÉ. Cet article analyse quelques figures periglaciaires de type Alpin, de la region de Morfee Mountain (B.C.) $\left(55^{\circ} 26^{\prime}, 123^{\circ} 04^{\prime}\right)$. Sur la face sud, le paysage Alpin commence à $1300 \mathrm{~m}$ jusqu'au sommet à $1650 \mathrm{~m}$. Les figures periglaciaires se situent de $1725 \mathrm{~m}$ au sommet. Restent quelques arbres au dessus de cette hauteur, dans de petites zones protégés, le long de ruisseaux. La zone Alpine est limitée vers le bas par le zone biogeoclimatique subalpine à sapins, tandis que les vallées entourant la montagne, sont dans la zone biogeoclimatique à sapins subboreaux. Ces sols n'ont pas été étudiés en detail mais vont des brumisols alpins aux gleysols et rendzines.

Six figures periglaciaires differentes s'observent et suggérent que les niveaux inferieurs du pergelisol et des figures periglaciaires, doivent monter progressivement le long d'une transversale N-S à travers la Cordilliere occidentale.

1) les sols polygonaux - tres abondants sur les terrains plats ou legérement inclinés; ils ont de 0.5 à $1.5 \mathrm{~m}$ sans vegetation,exposés au vent;

2) les gradins (steps) associés aux sols polygonaux, avec de la vegetation

3) les maillages (nets), developpés sous les mémes conditions que les polygones, pouvant étre en continuité avec eux;

4) les stries; elles apparaissent en bas de talus dans les zones à polygones;

5) les cercles dans les zones plates, de taille 0.5 à 2 métres de diametre;

6) les "felsenmeers", épendages dans des zones exposées à des vents violents transportant des galets legérs sur ces felsenmeers. Leurs emplacements dans la topographie suggérent l'idée de terrasse en altitude.

En conclusion l'auteur, souligne que la "Morfee Mountain" est un dndroit ideal pour étudier la geologie du pleistocene en climat temperé. Traduit par Alain de Vendegies, Aquitaine Co. of Canada.

\section{INTRODUCTION}

Landscapes characterized by patterned ground have been extensively studied and mapped in polar and high latitude regions where the presence of permafrost and its annual interplay with the active layer has been shown to be closely linked with periglacial phenomena and to patterned ground (Brown and Péwé, 1973; Corte, 1963; Washburn, 1956; 1973; Williams, 1960). Whether or not permafrost is a necessary condition for defining features as periglacial is much disputed. Washburn (1973) in his discussion of the term "periglacial" noted that Tricart (1967) considered permafrost, whether or not 
it is in balance with present climates, as a primary characteristic, though not a necessary condition, to defining the periglacial domain. Pewé (1969) essentially regarded permafrost as a necessary condition; however, Washburn (1967) suggests that this is too restrictive as it may preclude features such as gelifluction, frost creep and some forms of patterned ground associated with frost action though not necessarily permafrost. In this paper "periglacial" is used in the sense of Washburn (1967) to "... designate cold-climate, primarily terrestrial, nonglacial processes and features regardless of date or proximity of glaciers."

Although the link between patterned ground, other periglacial phenomena and permafrost is well established in northern latitudes, it is not as clear in more temperate regions. Woods (1977) and Ogilvie and Baptie (1967) suggest that areas of patterned ground in more southern climates may represent an active response by a landscape to its present climate rather than indicating past permafrost environments. Brown and Péwé (1973) in their discussion of permafrost and periglacial features in the Western Cordillera suggest that the lower altitude of permafrost should rise progressively along a north-south transect. Brown (1967), during his permafrost investigation in Northern British Columbia, noted that the lower elevation of permafrost occurrence was at $1200 \mathrm{~m}$ (3926 ft.), whereas Ives and Fahey (1971) observed its occurrence in Colorado at an elevation of $3500 \mathrm{~m}$ (11 $280 \mathrm{ft}$.). Scotter (1975) documented perennially frozen ground near Banff, Alberta at an elevation of $2665 \mathrm{~m}(8883 \mathrm{ft}$.).

Documentation of permafrost distribution and the distribution of patterned ground in the southern half of British Columbia and Alberta is sparse. Jennings (1951) reported stone nets in the Sunwapta area of Alberta at an elevation of $2500 \mathrm{~m}(8200 \mathrm{ft}$.); Rutter (1972) noted the presence of felsenmeer

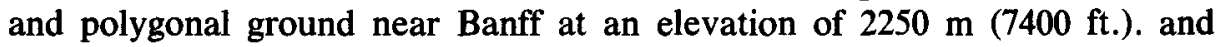
considered the area to be recently active primarily because of the fresh appearance of stones and the lack of vegetation. Bryant and Scheinberg (1970) studied vegetation on patterned ground on Plateau Mountain, Alberta and observed sorted circles and nets on flatter areas with a gradual transition to sorted steps and sorted stripes with increasing slope angle. Pheasant (1968) noted that patterned ground occurred on many of the flat topped summits near Yaha Tinda Creek in the front ranges of the Alberta Rocky Mountains.

The occurrence of features produced by intense frost action and related effects are particularly important in the interpretation of the Pleistocene history of an area. The location and nature of such features in the Western Cordillera and coastal ranges is particularly important because of the very complex glacial and deglacial sequences known to exist through the region.

When our knowledge of cordilleran glacial geology becomes more exact, the stage will be set for interpretation of botanical and consequently zoological recolonization sequences and rates, species variation, and evolutionary relationships. This paper describes several alpine periglacial features, which Washburn (1973) terms patterned ground, from the Misinchinka Range near Morfee Mountain (local name), British Columbia $\left(55^{\circ} 26^{\prime} \mathrm{N}, 123^{\circ} 02^{\prime} \mathrm{W}\right)$ (Fig. 1). 
PERIGLACIAL FEATURES

351

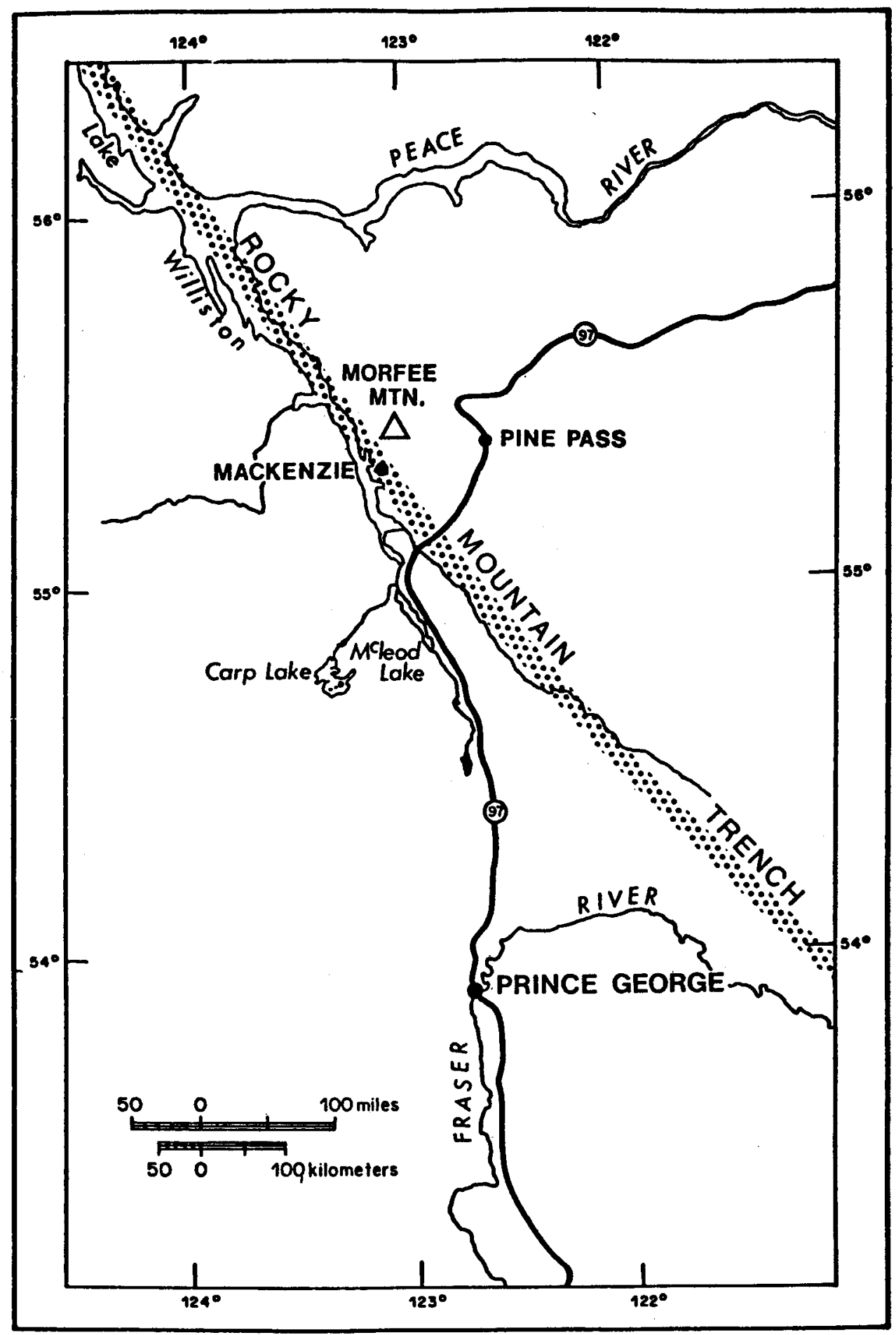

FIG. 1. The location of the study area at Morfee Mountain is indicated by triangle on the map. 


\section{STUDY AREA}

Strata on Morfee Mountain are of Precambrian and Paleozoic age and composed primarily of low grade metamorphic rocks (Müller, 1961). The southwestern slopes of the mountain contain primarily chlorite and sericite schist, phyllite, schistose grit and quartz pebble conglomerate. The summit is typified by black slate which covers the ground, slaty greywacke, minor quartzite and conglomerate. Cirques which form the headwaters of John Bennett Creek to the north are dominated by limestone and calcareous schist with minor slate and chlorite schist.

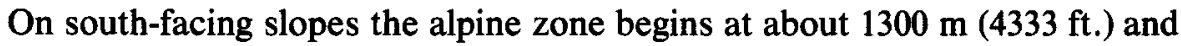
extends to the summit at $1650 \mathrm{~m}(5500 \mathrm{ft}$.). There are few trees above this elevation except for patches of krummholz Abies lasiocarpa (Hook.) Nutt. which grow in small protected areas along draws and minor drainage channels. The alpine zone is bounded at lower elevations by the Engelmann Spruce-Subalpine Fir Biogeoclimatic Zone while the river valleys surrounding the mountain are within the Subboreal Spruce Biogeoclimatic Zone (Krajina, 1965; Revel, 1972; 1979 (in press)). No detailed soil classification was developed; however, observations suggest a range from alpine brunisols through gleysols and rendzina soils to undifferentiated parent material.

\section{PERIGLACIAL FEATURES}

Six different periglacial features, distributed locally over an area of several $\mathrm{km}^{2}$, were noted by the author while conducting field survey under the British Columbia Ecological Reserves Programme in July and August 1971.

The location of the six features, by providing an additional elevation range, supports the suggestion of Brown and Péwé (1973) that the lower elevation of permafrost and periglacial features should rise progressively along a north-south transect through the Western Cordillera. The nature of the individual features would further support the gradational nature of patterning as suggested by Black (1952) and the essential continuum nature of forms between sorted polygons and sorted nets as suggested by Washburn (1973). The features include:

1) Sorted Polygons (Fig. 2). Very common on flat to gently sloping terrain. Frequently associated with exposed windswept ridges where the surface soil consists of coarse pebbles to fine cobbles interspersed throughout a fine- to medium-textured soil matrix. Size of the polygons ranged from 0.5 - $1.5 \mathrm{~m}$ across. Polygons observed were judged to be active because of the absence of vegetation in their centre, the dispersed nature of the water saturated fines in the centre and because many of the flat tabular stones rested on their edges.

2) Sorted Steps (Fig. 2). Commonly associated with sorted polygons and occasionally sorted nets which occur on and are restricted to gentle slopes. Typically the sorted steps observed had a tread diameter ranging from $0.5-1.5 \mathrm{~m}$ across and a riser height ranging from $5-22 \mathrm{~cm}$. Tread 
slope was clearly less than that of the general terrain slope angle. The riser in most cases was associated with and covered by vegetation, notably Betula glandulosa Michx., Salix reticulata L., S. polaris (Wahlenb.) Hult., Sibbaldia procumbens L., Solidago multiradiata Ait. and Phyllodoce aleutica (Speng.) Heller.

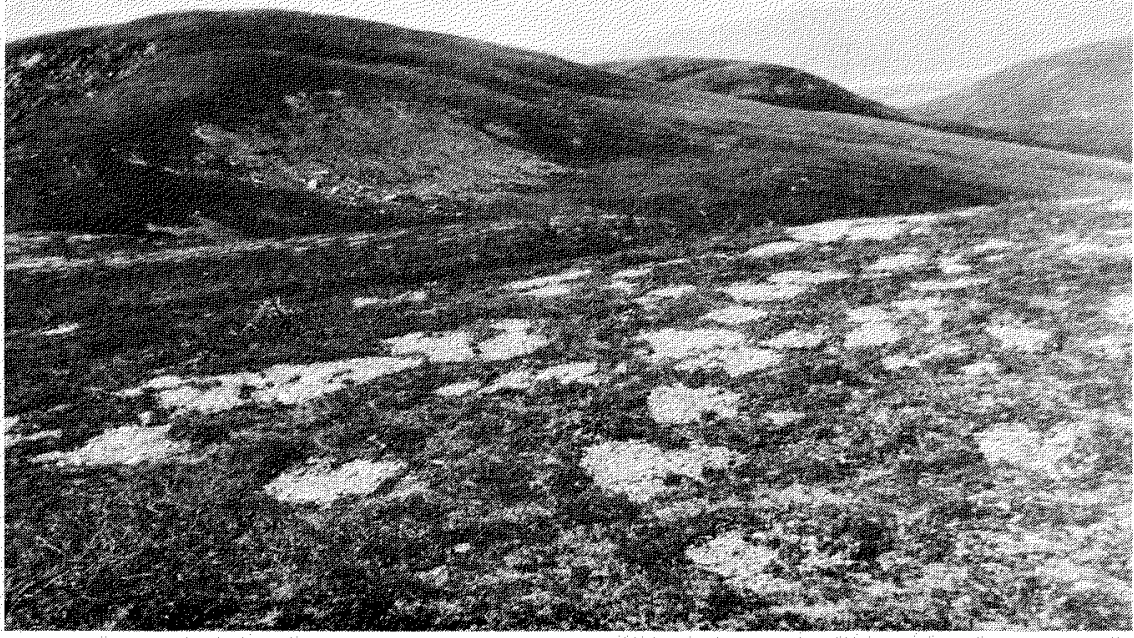

FIG. 2. Sorted polygons forming sorted steps on gentle slopes.

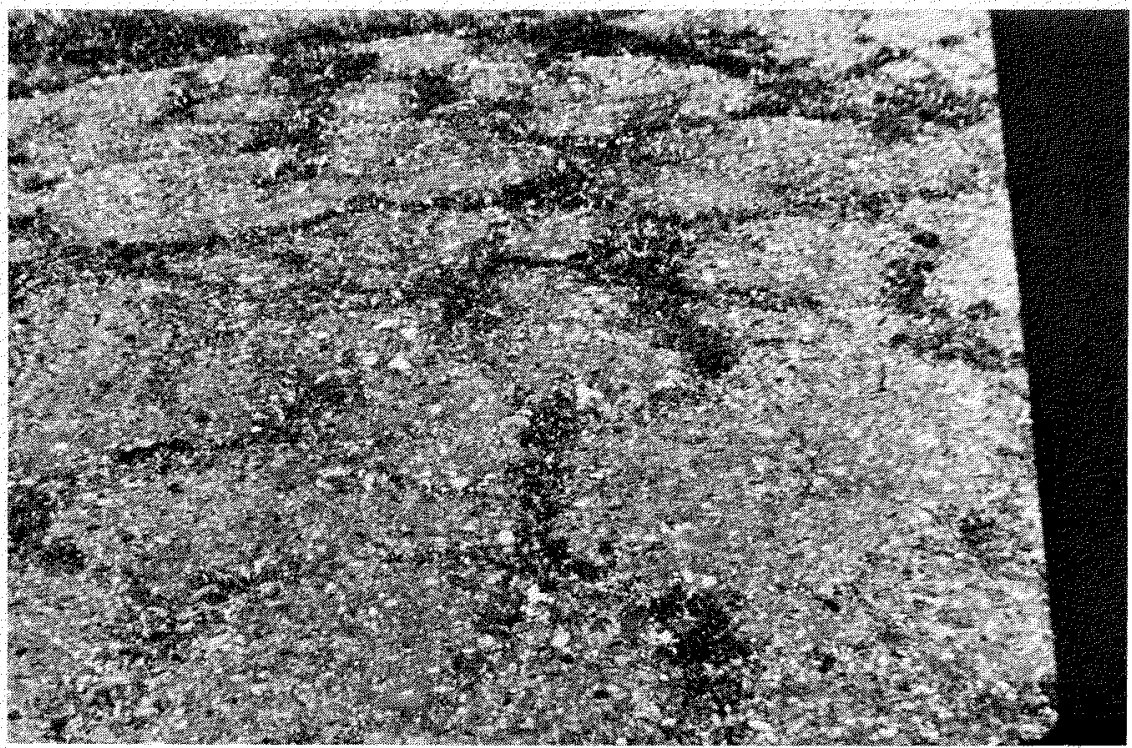

FIG. 3. Sorted nets showing sparse vegetation cover associated with coarser textured material around periphery of ground patterns: 
3) Sorted Nets (Fig. 3). Nets occur under similar conditions to sorted polygons and are occasionally intermixed with them. In some locations a complete continuum exists between sorted polygons and sorted nets. Betula glandulosa and Salix spp. were common on the net periphery. The sorted nets were judged to be active for the same reasons as sorted polygons.

4) Sorted Stripes (Fig. 4). Sorted stripes appear to be down-slope extensions of predominantly sorted polygons, and to a lesser extent of sorted nets. Figure 4 illustrates the transitional relationships with sorted polygons beginning to extend longitudinally parallel to the slope angle as it increases.

5) Sorted Circles (Fig. 5). Large stone rings were observed adjacent to a small alpine meltwater tarn on flat to slightly depressional terrain only. The circles ranged in size from $0.5-2.0 \mathrm{~m}$ in diameter with relatively fine circle centre material when compared with the coarse boulders up to 1.0 $\mathrm{m}$ across which form the periphery of the circle. Many of the tabloid-shaped stones rest on edge suggesting a degree of continued activity; however, the gradual vegetation colonization of the centres inward from the coarser circle periphery suggest that current activity is not as great as it had previously been.

6) Felsenmeer (Fig. 6). This feature is characterized by an abundance of tabloid-shaped stones (often slaty) which cover the surface. Dominant vegetation is Betula glandulosa and Salix spp. The area is frequently subjected to high velocity winds which pick up the lighter stones and redeposit them over the surface of the felsenmeer. The location of the felsenmeer relative to the surrounding topography would suggest that it may represent an altiplanation terrace; however, further investigation is required to substantiate this.

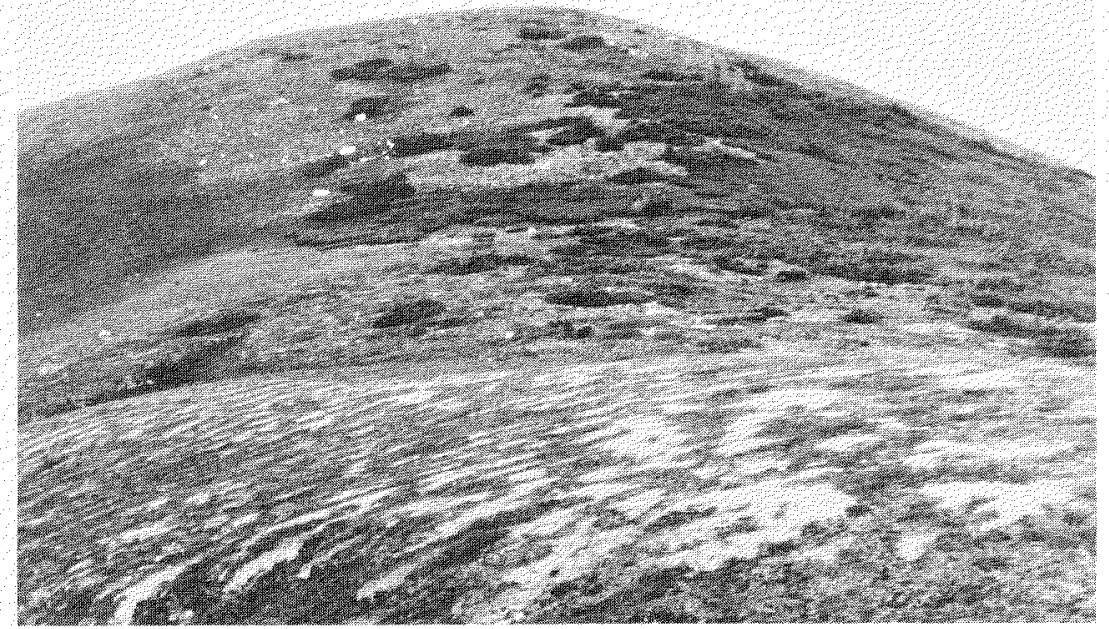

mis. 4. Sorted polygons showing transition to sorted stripes with increasing slope. 


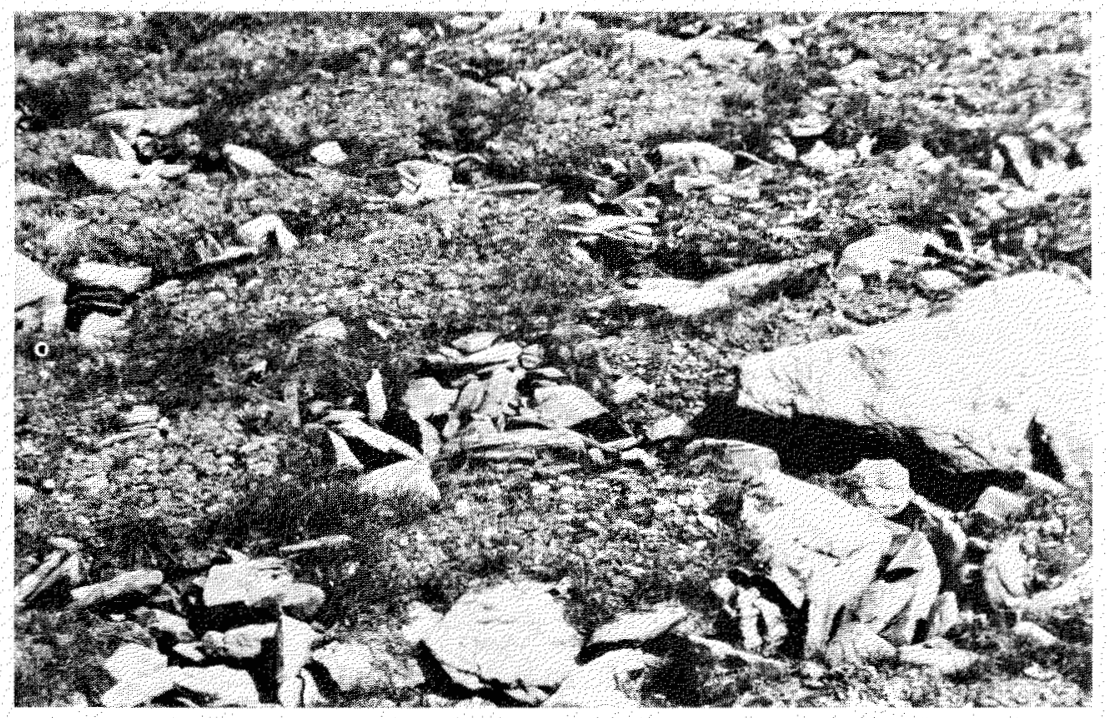

FIG. 5. Stone rings showing circular border of angular boulders enclosing a gently domed interior of finer textured material. Rings located in depression near small alpine tarn. Large boulder is approximately $1 \mathrm{~m}$ long.

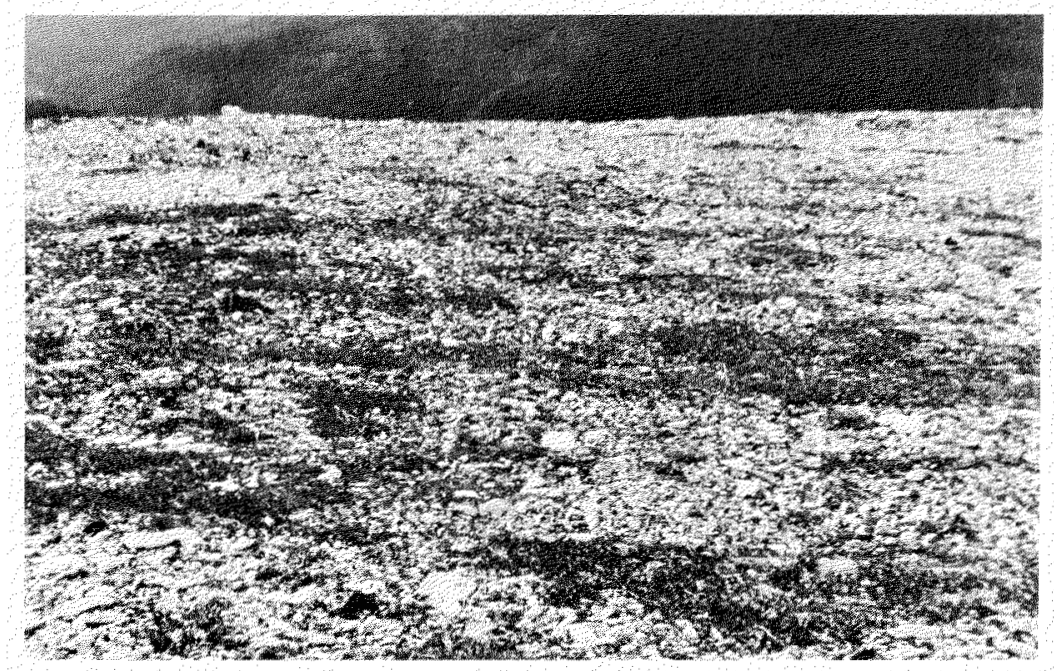

FIG. 6. Felsenmeer type of feature with patchy growth of willow and dwarf birch. Pieces of slate are frequently airborne during frequent high winds.

\section{REFERENCES}

BLACK, R.F. 1952. Polygonal patterns and ground conditions from aerial photographs. Photogrammetrical Engineering 18: 123-134.

BROWN, R.J.E. 1967. Permafrost investigations in British Columbia and Yukon Territory. Technical Paper No. 253. National Research Council of Canada, Ottawa. 54 pp. 
and PÉWE, T.L. 1973. Distribution of permafrost in North America and its relationship to the environment: a review, 1963-1973. Technical Paper No. 411. National Research Council of Canada, Ottawa. $100 \mathrm{pp}$.

BRYANT, J.P. and SCHEINBERG, E. 1970. Vegetation and frost activity in an alpine fellfield on the summit of Plateau Mountain, Alberta. Canadian Journal of Botany 48(4): 751-563.

CORTE, A.E. 1963. Relationship between four ground patterns, structure of the active layer and the type and distribution of ice in the permafrost. Biuletyn Peryglacjalny 12: 7-90.

DEMEK, JARAMER. 1969. Cryoplanation terraces, their geographical distribution, genesis and development. Ceskoslovenski Akademie ved Prague. Rada Matematickych a Pairodmich ved, Rosprovy, Rocnik 79(4).

HUGHES, O.L., RAMPTON, V.N., and RUTTER, N.W. 1972. Quaternary geology and geomorphology, southern and central Yukon (Northern Canada). In: Guidebook, Field Excursion A11. XXIV International Geologic Congress, Montreal.

IVES, J.D. and FAHEY, D. 1971. Permafrost occurrence in the Front Range, Colorado Rocky Mountains. Journal of Glaciology 10(58): 105-111.

JENNINGS, A.H. 1951. The glacial geomorphology of the Sunwapta Pass area, Jasper National Park, Alberta, Canada. Unpublished M.Sc. Thesis. Department of Geology, University of Iowa.

KRAJINA, V.J. 1965. Biogeoclimatic zones and classification of British Columbia. Ecology of Western North America 1: 1-17.

MÜLLER, D. 1961. Geology of Pine Pass, British Columbia, Map 11-1961. Geological Survey of Canada, Department of Mines and Technical Surveys, Ottawa.

OGILVIE, R.T. and BAPTIE, B. 1967. A permafrost profile in the Rocky Mountains of Alberta. Canadian Journal of Earth Sciences 4: 774-775.

PÉWÉ, T.L. 1969. The periglacial environment: 1-9. In: Péwé, T.L. (ed.). The Periglacial Environment. Montreal: McGill-Queen's University Press. 487 pp.

PHEASANT, D.R. 1968. The glacial geomorphology of the Yaha Tinda Area, Alberta. Unpublished M.Sc. Thesis. Department of Geography, University of Calgary, Alberta. 121 pp.

REVEL, R.D. 1972. Phytogeocoenoses of the Sub-boreal Spruce Biogeoclimatic Zone in north central British Columbia. Ph.D. Thesis. Department of Botany, University of British Columbia. 409 pp.

- In press. New records of alpine plants from Morfee Mountain, British Columbia. Canadian Field-Naturalist.

RUTTER, N.W. 1972. Geomorphology and multiple glaciation in the area of Banff, Alberta. Bulletin 206. Geological Survey of Canada, Ottawa. 54 pp.

SCOTTER, G.W. 1975. Permafrost profiles in the Continental Divide region of Alberta and British Columbia. Arctic and Alpine Research 7(1): 93-95.

TRICART, J. 1967. Le Modèle des régions périglaciaires. In: Tricart, J. and Cailleux, A. Traité de Geomorphologie 2. SEDS, Paris. 512 pp.

WASHBURN, A.L. 1956. Classification of patterned ground and review of suggested origins. Bulletin of the Geological Society of America 67: 823-866.

- 1967. Instrumental observations of mass-wasting in the Mesters Vig District, Northeast Greenland. Meddelelser om Grönland 176(4). 303 pp.

- 1973. Periglacial processes and environments. London: Edward Arnold Publishing. 320 pp.

WILLIAMS, P.J. 1960. The development and significance of stony earth circles. Research Paper No. 91. National Research Council of Canada, Ottawa. 14 pp.

WOODS, C.B. 1977. Distribution and selected characteristics of high altitude patterned ground in the summit area of Plateau Mountain, Alberta. Unpublished M.Sc. Thesis. Department of Geography, University of Calgary, Alberta. $171 \mathrm{pp}$. 